\title{
PEREMPUAN DALAM PERKEMBANGAN ILMU PENGETAHUAN DAN TEKNOLOGI
}

\author{
Nur Wakhidah, M.Si \\ Dosen Jurusan Biologi Fakultas Saintek UIN Malang
}

\begin{abstract}
Abstrak
The development of science and technology influence all aspects of life. The development is not only dominated by men but also by women. Women are considered as the user of the invention of science and technology while men are the inventor. Men, explicitely, pose role in the process of science and technology. However, scienctists propose findings that show women's identity of technology. It is predicted by those who are concerned with women issues that there will be more women involving in the process of inventions in science and technology. This achievement of women is inevitable as they have contributed much on the development of that area whether it is publicly accepted or not.
\end{abstract}

\section{A. Pendahuluan}

Perkembangan ilmu pengetahuan dan teknologi dewasa ini sangat pesat seiring dengan kebutuhan dan kemudahan hidup yang diinginkan oleh manusia. Ilmu pengetahuan tercipta berdasarkan pengalaman dan observasi yang akhirnya terakulumasi menjadi sebuah ilmu pengetahuan. Pada dasarnya perkembangan ilmu pengetahuan dan teknologi juga sejalan dengan perkembangan masyarakat dan perubahan sosial. Definisi teknologi secara luas adalah penggunaan unsur-unsur praktis secara rasional untuk mencapai suatu tujuan tertentu. Masyarakat dengan bermacam adat istiadatnya secara sengaja atau tidak sengaja akan berperan sebagai pencipta dan pengguna teknologi. Teknologi yang digunakan oleh masyarakat tertentu menunjukkan prosedur yang digunakan dalam menemukan, memproduksi, menggunakan serta merawatnya.

Perkembangan ilmu pengetahuan dan teknologi saat ini berjalan dengan sangat cepat terutama sejak abad ke-20. Perkembangan ini meliputi teknologi di bidang pertanian, industri, transportasi, komputasi, kesehatan/kedokteran, persenjataan, komunikasi dan informasi. 
Keberadaan teknologi ini di dalam masyarakat tidak terlepas dari perkembangan masyarakat itu sendiri. Teknologi merupakan salah satu bagian dari peradaban masyarakat.

Adanya peningkatan jumlah penduduk akan mengakibatkan peningkatan jumlah kebutuhan akan bahan pangan. Pengembangan teknologi di bidang pertanian didorong oleh adanya penyempitan lahan pertanian dan pengurangan jumlah tenaga kerja di bidang pertanian yang beralih profesi sebagai pekerja industri. Kebutuhan akan barang-barang seperti tekstil, makanan dalam kaleng, dan lain-lain akan mengembangkan teknologi di bidang industri. Adanya peningkatan aktivitas manusia yang terhalang oleh jauhnya jarak tempuh akan menyebabkan teknologi transportasi kian berkembang.

Penghitungan sederhana dengan menggunakan kalkulator dirasa sudah sangat ketinggalan sehingga teknologi komputasi kian berkembang. Dengan menggunakan teknologi manusia dapat dimanjakan dalam memecahkan masalah, termasuk dalam mengolah data penelitian dan membuat rancang bangun dan dalam rangka menciptakan teknologi baru. Dunia seakan-akan tanpa batas setelah perkembangan teknologi komunikasi dan informasi. Dengan internet kita dapat mengakses segala informasi yang ada di dunia dalam hitungan detik atau bahkan sepersekian detik

Perkembangan teknologi tidak akan pernah lepas dari perkembangan ilmu dasar yang mendasari teknologi. Research and development (R \& D) akan sangat menentukan teknologi terutama teknologi canggih. Di Indonesia pengembangan ilmu dasar kurang begitu diperhatikan karena keterbatasan masalah dana, sedangkan hasil dari penelitian dan pengembangan ilmu dasar itu sendiri tidak secara langsung dapat dinikmati oleh masyarakat. Pengembangan teknologi di negara kita cenderung ke arah teknologi alternatif atau teknologi tepat guna dimana manfaatnya dapat diakses langsung oleh masyarakat. Padahal pengembangan teknologi tidak terlepas dari pengembangan ilmu dasar yang mendasari teknologi seperti matematika, fisika, kimia dan biologi.

Berkaitan dengan masalah teknologi kita dapat membedakan antara kelompok yang menciptakan teknologi dan menggunakan teknologi. Kita termasuk kedalam kelompok yang sebagian besar merupakan pengguna teknologi. Masyarakat kita adalah adalah masyarakat yang sangat heterogen, dengan tingkat pendidikan yang sangat beragam. Untuk menjadi sebuah komunitas yang modern diharapkan masyarakt kita tidak gagap teknologi atau melek teknologi. Dari segi sosiologi memang dalam masalah adopsi teknologi ada yang mempunyai 
kecenderungan untuk menerima teknologi sebagai sesuatu yang lebih menguntungkan, sebaliknya ada sebagian masyarakat memandang bahwa teknologi akan membuat orang mempunyai pola kehidupan yang konsumtif. Sebagai kelompok yang sekarang dalam kapasistas sebagai pengguna teknologi diharapkan pada masa mendatang kita juga dapat menjadi pencipta teknologi, karena berlatar belakang dari keingintahuan akan teknologi dan keinginan untuk mengembangkan teknologi tersebut lebih lanjut.

Kehidupan bermasyarakat yang menyangkut penciptaan dan penggunaan teknologi maka akan melibatkan semua jenis kelamin baik perempuan maupun laki-laki. Dalam kehidupan sosial kemasyarakatan seringkali peran perempuan dan laki-laki. Bila kita membicarakan tentang masalah teknologi maka seolah-olah teknologi hanya merupakan milik dalam arti laki-lakilah yang dapat menciptakan teknologi yang canggih seperti pesawat terbang. Stigmatisasi terkadang muncul bahwa perkembangan ilmu pengetahuan dan teknologi hanya menjadi dominasi bagi kaum laki-laki.

Sebenarnya banyak sekali peran perempuan dalam perkembangan ilmu pengetahun dan teknologi, akan tetapi hal ini tidak akan nampak di permukaan karena adanya pembedaan menurut kultur sosial budaya. Hal inilah yang akhirnya akan menimbulkan bias gender. Perempuan dianggap sebagai 'konco wingking' yang tidak berperan dalam pengembangan iptek. Menurut Sukesi ${ }^{1}$ gender adalah kontruksi sosial budaya yang membedakan antara perempuan dan laki-laki dalam kehidupan bermasyarakat.

Secara historis-sosiologis ilmuwan yang menganut faham feminisme telah mempertanyakan hubungan antara gender dan ilmu pengetahuan (terutama sains) sejak tahun 70-an. Banyak ilmuwan yang berhasil menemukan temuan baru yang mempunyai identitas perempuan. Para pemerhati perempuan memprediksikan bahwa dimasa yang akan datang akan lebih banyak lagi ilmuwan perempuan yang muncul ke permukaan dalam pergulatan ilmu pengetahuan. Prestasi perempuan tidak dapat dipungkiri lagi. Perempuan sudah banyak memberi kontribusi terhadap perkembangan ilmu pengetahuan dan teknologi. ${ }^{2}$

${ }^{1}$ Suksesi, K. 2005. Pengarusutamaan Gender Dalam Kelembagaan Riset Ilmu Pengetahuan dan Teknologi (Riptek). Malang: Makalah Disampaikan Dalam Seminar Pengarusutamaan Gender Dalam Program Peningkatan Saran dan Kelembagaan Iptek.

${ }^{2}$ Waejman, J. 2001. Feminisme versus Technology. SDPY-Oxfarm - UK - 1 


\section{B. Teknologi ; Definisi dan Perkem bangannya}

Anglin $^{3}$ mendefinisikan teknologi sebagai penerapan ilmu-ilmu perilaku dan alam serta pengetahuan lain secara bersistem untuk memecahkan masalah. Alisyahbana ${ }^{4}$ merumuskan bahwa teknologi adalah cara melakukan sesuatu untuk memenuhi kebutuhan manusia dangan bantuan alat dan akal sehingga seakan-akan memperpanjang, memperkuat, atau membuat lebih ampuh anggota tubuh, panca indera dan otak manusia.

Dorf mengartikan teknologi sebagai aplikasi sains, sedang Synder (1981) mengartikan teknologi sebagai pengetahuan dan studi usaha manusia dalam menciptakan dan menggunakan alat, teknik, sumber daya dan sistem untuk mengelola lingkungan alam dan lingkungan buatan manusia untuk tujuan memperbaiki kehidupan. Goethsch dan Nelson (1987) mengartikan teknologi sebagai kombinasi alat, sumber daya dan proses yang dijiwai oleh manusia untuk mamecahkan masalah atau untuk memperluas kapabilitasnya.

Dari pengertian di atas maka manusia tidak pernah lepas dari teknologi. Teknologi merupakan keseluruhan cara yang secara rasional mengarah pada ciri efisien dalam setiap kegiatan manusia. Seseorang menggunakan teknologi karena manusia berakal. Dengan akalnya manusia ingin keluar dari masalah, ingin hidup lebih baik, lebih mudah dan aman. Perkembangan teknologi terjadi ketika seseorang dengan menggunakan alat dan akalnya menyelesaikan masalah yang dihadapinya.

Perkembangan teknologi secara eksplisit sangat berhubungan dengan perkembangan masyarakat. Definisi teknologi secara luas adalah penggunaan unsur-unsur praktis secara rasional untuk mencapai tujuan tertentu. Teknologi dalam masyarakat tertentu menunjukkan prosedur yang digunakan dalam menemukan, memproduksi, menggunakan seta perawatannya. Determinisme teknologi dapat mengakibatkan konsekuensi sosial yang bersifat drastis. Masyarakat yang memilih teknologi alternatif pada umumnya disebabkan karena alternatif tersebut sesuai dengan tatanan masyarakat yang berlaku.

\footnotetext{
${ }^{3}$ Anglin, GJ. Instructional Technology: Past, Present and Future. Englewood: Libraries UnLimited,

${ }^{4}$ Alisyahbana, I. Teknologi dan Pekembangan. Jakarta: Yayasan Idayu, 1980.
} 1991. 
Teknologi pada masyarakat tertentu menunjukkan alat-alat yang digunakan oleh anggota masyarakat. Syaodih (dalam Sutjipto) ${ }^{5}$ menyatakan bahwa sebenarnya sejak dulu teknologi sudah ada atau manusia sudah menggunakan teknologi. Kalau manusia pada zaman dahulu memecahkan kemiri dengan menggunakan batu atau memetik buah dengan galah akan tetapi sesungguhnya mereka telah menggunakan teknologi yaitu teknologi sederhana. Pembahasan populer terhadap teknologi pada umumnya difokuskan pada perkembangan akhir dari teknologi serta masalah-masalah yang kait dengan bidang persenjataan, pengobatan, komputasi, komunikasi, transportasi, penerbangan, pertanian dan industri, meskipun tusuk gigi, kancing baju, palu, gunting pada jamannya juga termasuk hasil dari teknologi. Kemajuan teknologi akan pudar bila bentuk teknologi baru yang lebih menjanjikan dan lebih canggih ditemukan.

Peradapan utama dari zaman kuno yang teknologinya berkembang di atas masyarakat primitif mampu memproduksi temuan-temuan berupa mesin-mesin yang sampai sekatang masih digunakan. Teknologi kuno berkembang sangat lambat jika dibanding dengan perkembangan teknologi modern. Pada zaman sekarang jarak perkembangan teknologi adalah sangat drastis. Revolusi industri yang mulai berkembang pada abad ke 19 yang berupa pengembangan teknologi listrik, mesin dan kimia maka sekarang berkembang menjadi teknologi informasi. ${ }^{6}$

Salah satu contoh perkembangan teknologi yang paling sering kita jumpai di dalam masyarakat adalah perkembangan teknoloagi komputer. Pada tahun delapan puluhan komputer XT merupakan personal komputer yang dianggap maju pada jamannya. Setelah itu perkembangan komputer jenis AT terjadi pada awal tahun 1990 an. Teknologi komputer sangat cepat sekali berkembang seiring dengan tuntutan kebutuhan dalam masyarakat akan kecepatan akses dan kemudahan serta kecanggihan program-programnya. Perkembangan teknologi komputasi dapat melalui dua cara yaitu perkembangan perangkat lunak (soft ware) dan perangkat keras (hard ware). Sejak tahun 1995 an berkembanglah komputer jenis Pentium, yang mempunyai kecepatan akses lebih tinggi sehingga menjanjikan bagi penggunanya.

\footnotetext{
${ }^{5}$ Suctipto. 2001. Kurikulum Pendidikan Teknologi Suatu Kebutuhan Yang Tidak Pernah Terlambat. Jakarta: Balitbang Disdasmen.

${ }^{6}$ Bell, Daniel. 1989. The Third Technological Revolution. Dissent Spring. 164-176.
} 
Tugas utama teknologi pada zaman kuno adalah untuk mencari cara bagaimana tenaga manusia atau binatang dapat dikombinasikan atau digantikan. Teknologi modern mengadopsi hal tersebut dalam bentuk yang lain. Kecanggihan teknologi modern bahkan tidak hanya menggantikan tenaga manusia dengan menggunakan mesin. Perkembangan bisnis modern kadang-kadang mentransfer pekerjaan dari pegawai mereka ke konsumen dan tidak mentrasnfer pekerjaan pegawai ke mesin. Sebagai contoh di supermarket yang biasanya orang belanja dilayani oleh pegawai maka pelayaan ini digantikan oleh konsumen sendiri melalaui istilah swalayan (melayani diri sendiri). Zaman globalisasi dan era keterbukaan teknologi informasi memberikan layanan barang dan jasa kepada konsumen menjadi lebih dipermudah dengan mengakses barang-barang belanjaan di internet melalui situs e-commerce.

\section{Teknologi dan Kemudahan Hidup Bagi Perempuan}

Banyak sekali teknologi yang diciptakan oleh manusia dapat mempermudah pekerjaan perempuan. Teknologi tersebut adalah teknologi yang diciptakan untuk membuat perempuan menjadi lebih nyaman dan mudah dalam menjalankan aktivitasnya bukan teknologi yang secara eksplisit akan mempermudah pekerjaan perempuan akan tetapi secara implisit akan membuat perempuan mengalami tekanan psikologis dan fisik akibat adanya teknologi tersebut. Teknologi pertama yang diciptakan oleh perempuan yang dapat mempermudah pekerjaan perempuan adalah teknologi botol susu.

Pada zaman dahulu bayi yang dilahirkan pada bulan-bulan awal secara otomatis menggunakan asi (air susu ibu) eksklusif, di mana makanan bayi tidak mendapat formulasi dari luar tubuh ibu. Pada keadaan demikian maka seorang perempuan yang baru melahirkan beberapa jam sudah harus melakukan aktivitas untuk menyusui bayinya. Pada perempuan yang berada pada area domestik (sebagai ibu rumah tangga) hal ini tidak akan menjadi masalah. Apabila seorang perempuan yang bekerja atau bagi perempuan yang mempunyai kelainan pada putting susu sehingga akan mengalami kesulitan saat menyusui maka suatu teknologi diperlukan bagi seorang perempuan. Teknologi pertama yang diciptakan oleh seorang perempuan adalah teknologi botol susu. Dengan adanya teknologi ini maka aktivitas menyusui tidak harus sepenuhnya dilakukan oleh perempuan akan tetapi pekerjaan ini juga dapat dilakukan oleh laki-laki setelah ASI ditampung di dalam botol. 
Pekerjaan perempuan lain yang sangat terbantu dengan adanya teknologi adalah aktivitas mencuci. Dalam pandangan kultur kita mencuci adalah perkerjaan pada ranah domestik yang menjadi tanggung jawab perempuan. Dengan adanya teknologi mesin cuci maka pekerjaan perempuan menjadi lebih ringan karena seorang laki-laki dapat melakukan aktivitas tesebut.

Sebenarnya masih banyak pekerjaan perempuan yang terbantu dengan adanya teknologi seperti adanya teknologi mesin penggilingan beras atau jagung. Penyiapan makanan menjadi tanggung jawab perempuan. Dengan adanya mesin penggilingan maka waktu perempuan untuk menyiapkan makanan menjadi lebih singkat dan energi yang dihasbiskan akan lebih sedikit sehingga perempuan dapat melakukan aktivitas yang lain seperti merawat anak. Selain itu teknologi kompor minyak juga sangat membantu perempuan dalam aktivitas untuk menyiapkan makanan. Adanya kompor minyak atau kompor gas akan memperingan perkerjaan perempuan karena tidak harus capek ke hutan untuk mencari kayu bakar dan meniup api.

Meskipun banyak sekali teknologi yang mempermudah pekerjaan perempuan seperti penanak nasi (rice cooker), dispenser, slicer, pemarut kelapa dan lain-lain, ${ }^{7}$ akan tetapi jika kita membahas mengenai teknologi yang menyangkut soal perempuan sebenarnya kita harus memandangnya dalam dua hal yaitu akses dan dampak bagi perempuan. Banyak sekali teknologi yang secara langsung atau tidak langsung diciptakan oleh perempuan. Paling tidak perempuan mempunyai suatu ide untuk mempermudah dalam melakukan pekerjaannya.

Menurut Sukesi $^{8}$ perempuan tidak nampak sebagai pencipta teknologi meskipun terdapat bukti bahwa perempuanlah yang menemukan mesin pemecah biji kapas, mesin jahit, penuai dan mesin tenun. Suatu teknologi memang dapat diakses oleh perempuan akan tetapi justru karena perempuan dapat mengakses teknologi tersebut maka perempuan malah justru terkena dampaknya. Bagaimana dengan adanya teknologi reproduksi bagi perempuan?

${ }^{7}$ Cahyani, Chandrawati. 2005. Pengarusutamaan Gender Dalam Kelembagaan Riset Ilmu Pengetahuan dan Teknologi (Riptek). Malang: Makalah Disampaikan Dalam Seminar Pengarusutamaan Gender Dalam Program Peningkatan Saran dan Kelembagaan Iptek. 


\section{Isu Gender dan IPTEK}

Disadari atau tidak peran perempuan sangatlah besar artinya dalam bidang pembangunan bangsa. Peran ini tidak saja dalam keadaan sekarang setelah perang kemerdekaan. Perempuan pada jaman revolusi untuk mencapai kemerdekaan juga sangat berperan, sebagai contohnya banyak tokoh dan pejuang perempuan seperti Cut Nyak Din, Cut Mutia, Dewi Sartika dan lain-lain. Meskipun peran tersebut tidak secara eksplisit seperti sekarang maka perempuan tidak dapat dipisahkan dari pembangunan.

Pada jaman modern seperti sekarang ini peran tidak diragukan lagi. Banyak perempuan yang sekarang ini bekerja pada sektor publik sebagai guru, dokter, pengacara, politikus, polisi, ekonom, bahkan sebagai presiden. Perempuan yang bekerja di sektor publik secara naruliyah tidak dapat terlepas begitu saja dari image perempuan yang identik dengan sektor domestik. Bagi perempuan bekerja di luar rumah maka kesuksesan dalam bidang profesi yang ditekuni bukan berarti kesuksesan dalam hidupnya. Bila seorang perempuan sangat sukses di dalam karir maka orang akan berkata nanti dulu bagaimana dengan rumah tangganya?

Peran ganda perempuan akan membuat perempuan memikul beban yang sangat berat karena di satu pihak perempuan yang sudah terjun ke dalam sektor publik harus mempunyai tanggung jawab dalam profesinya sama dengan laki-laki. Sebagai contoh seorang staf administrasi laki-laki mempunyai tugas yang sama dengan seornag administrasi perempuan. Padahal seorang perempuan dan laki-laki di rumah dalam hal pekerjaan belum tentu ada sebuah kesetaraan. Betapa berat beban perempuan untuk menjadi modern dengan peran ganda tersebut ${ }^{9}$.

Meskipun ilmu pengetahuan dan teknologi telah menawarkan banyak kesempatan baru bagi perempuan dan laki-laki, kenyataan menunjukkan bahwa partisipasi perempuan masih lebih rendah daripada laki-laki baik di bidang rekayasa, dan ilmu pengetahuan dan teknologi pada umumnya. Dampak selanjutnya dari rendahnya partisipasi adalah hilangnya kesempatan untuk berperan sentral dalam pembangunan sosial dan ekonomi. Selain itu juga akan menghilangkan kreativitas perempuan.

\footnotetext{
${ }^{8}$ Sukesi, op. cit.

${ }^{9}$ Irvanus, Edwin. Dilema Peran Ganda Perempuan Bekerja. Jakarta: Sinar Harapan. 2002.
} 
Adanya fenomena tersebut maka UNESCO bekerjasama dengan LIPI untuk membentuk sekretariat regional untuk gender, ilmu pengetahuan dan teknologi di kawasan Asia Pasifik. Pembentukan badan ini merupakan perwujudan dari rekomendasi konferensi Dunia Perempuan dan konferensi Dunia tentang pengetahuan. Sekretariat tersebut diharapkan dapat meningkatkan peran serta perempuan khususnya dalam ilmu pengatahuan dan teknologi. Selain itu pusat penelitian dan pengembangan kependudukan dan ketenagakerjaan LIPI juga mengutamakan gender mainstreaming dalam kegiatan peenelitian. Adanya hal ini diharapkan akan menciptakan lingkungan yang kondusif bagi tercapainya kesetaraan gender di bidang iptek. ${ }^{10}$

Perempuan memainkan peran penting dalam pembangunan ekonomi di negara berkembang melalui peran triplenya yaitu dalam pengelolaan masyarakat, reproduksi dan produksi. Perempuan berperaen dalam produksi energi dan air, perawatan kesehatan meningkatkan pendapatan keluarga menyelenggarakan pendidikan dan lain lain. UNESCO telah membentuk Jaringan yang berupaya untuk menghubungkan perempuan dengan perkembangna iptek. Pemerintah Indonesia dalam hal ini melalui menteri pemberdayaan perempuan telah memformulasikan beberapa misi dalam rangka meningkatkan kualitas hidup perempuan dengan mengintensifkan advokasi kesamaan gender, mengeliminasi semua bentuk kekerasan terhadap perempuan, meningkatkan perlidungan dan kesejahteraan terhadap perempuan dan anak, meningkatkan kapasitas organisasi perempuan.

\section{E. Gender Mainstreaming dan IPTEK}

Kebijakan strategik Pembangunan Nasional ilmu pengetahuan dan teknologi (Jakstranas) tahun 2005-2009 disusun sebagai pedoman untuk arah kebijakan dan kerangka kebijakan bagi seluruh pelaku pembangunan iptek. Sesuai dengan amanat UUD 1945 pemerintah berkewajiban untuk memajukan iptek dengan menjunjung tinggi nilai keagamaan dan persatuan bangsa untuk kemajuan peradapan serta kesejahteraan umat manusia. Visi iptek 2025 adalah iptek sebagai kekuatan utama peningkatan kesejahteraan yang

\footnotetext{
${ }^{10}$ Kompas.. Partisipasi Iptek Perempuan Rendah. Jakarta: Rubrik Kompas, 2000
} 
berkelanjutan dan peradapan bangsa. Untuk mewujudkan visi tersebut maka misinya adalah: ${ }^{11}$

1. menempatkan iptek sebagai landasan kebijakan pembangunan nasional yang berkelanjutan

2. memberikan landasan etika bagi pengembangan dan penerapan iptek

3. mewujudkan sistem inovasi nasional yang tangguh guna meningkatkan daya saing bangsa di era globalisasi

4. meningkatkan difusi iptek melalui pemantapan jaringan pelaku dan kelembagaan iptek, termasuk pengembangan mekanisme dan kelembagaan intermediasi iptek

5. mewujudkan SDM, sarana prasarana serta kelembagaan iptek yang berkualitas dan kompetitif

6. mewujudkan masyarakat Indonesia yang cerdas kreatif dalam suatu peradapan masyarakat yang berbasis pengetahuan

Akses perempuan di bidang iptek masih terkendala oleh ketidaksetaraan gender. Hal ini disebabkan oleh peran perempuan yang banyak sebagai pengguna dari produk iptek bukan sebagai kreator. Hal ini terutama sekali terjadi pada perempuan di negara sedang berkembang. Negara berkembang merupakan lahan yang menumbuh suburkan ketidaksetaraan antara laki-laki dan perempuan dalam akses iptek. Hal ini disebabkan tingkat pendidikan perempuan yang lebih rendah daripada laki-laki. Permasalah yang melatarbelakangi hal tersebut adalah bersifat klasik yaitu masalah kemiskinan. Masalah ini menjadi suatu penyebab utama mengapa perempuan menjadi tidak bersekolah. UNESCO mencatat bahwa penduduk dunia yang menderita buta huruf kebanyakan adalah perempuan. ${ }^{12}$ Rakyat miskin di dunia juga didominasi oleh perempuan.

Rendahnya peran perempuan dalam iptek juga dipicu oleh masih rendahnya tingkat pendidikan perempuan secara umum. Meskipun di kota-kota besar banyak sekali perempuan yang mempunyai tingkat pendidikan puncak akan tetapi kalau dalam skala makro maka keterwakilan perempuan dalam bidang iptek masih tergolong sangat rendah.

11 Wijanarko, N. Pengarusutamaan Gender Dalam Kelembagaan Riset Ilmu Pengetahuan dan Teknologi (Riptek). Malang: Makalah Disampaikan Dalam Seminar Pengarusutamaan Gender Dalam Program Peningkatan Saran dan Kelembagaan Iptek.

${ }^{12}$ Siswono. 2004. Ketidaksetaraan Gender Tutup Akses Perempuan Di bidang Iptek. Jakarta: gizi.net. 
Wati Hernawati Programme Coordinator Gender, Science and Technology menyatakan bahwa untuk mencapai kesetaraan gender dalam iptek masih sangat sulit untuk dilakukan karena dalam tataran policy gender mainstreaming masih sulit untuk diterapkan.

Bagi yang tidak memahami masalah gender selalu ada kesan bahwa iptek tidak mempunyai persoalan gender. Harus diakui bahwa perkembangan ilmu pengetahuan dan teknologi akan memaksa perempuan untuk mengembangkan iptek karena perempuan pada zaman sekarang tidak hanya sebagai pengguna iptek saja akan tetapi juga berperan sebagai kreator. Adanya kebijakan/policy yang berpihak kepada kesetaraan gender maka diharapkan akan menambah peluang bagi perempuan untuk menapaki dunia iptek. 


\section{DAFTAR PUSTAKA}

Alisyahbana, I. 1980. Teknologi dan Pekembangan. Jakarta: Yayasan Idayu.

Anglin, GJ. 1991. Instructional Technology: Past, Present and Future. Englewood: Libraries UnLimited .

Bell, Daniel. 1989. The Third Technological Revolution. Dissent Spring. 164-176.

Cahyani, Chandrawati. 2005. Pengarusutamaan Gender Dalam Kelembagaan Riset Ilmu Pengetahuan dan Teknologi (Riptek). Malang: Makalah Disampaikan Dalam Seminar Pengarusutamaan Gender Dalam Program Peningkatan Saran dan Kelembagaan Iptek.

Habibie, BJ. 1983. Beberpa Pemikiran Tentang Strategi Transformasi Industri Suatu Negara Sedang Berkembang. Jakarta: Menristek.

Irvanus, Edwin. 2002. Dilema Peran Ganda Perempuan Bekerja. Jakarta: Sinar Harapan.

Kompas. 2000. Partisipasi Iptek Perempuan Rendah. Jakarta: Rubrik Kompas.

Lisiani, T. 2005. Perempuan, Kebijakan Iptek dan HAM di Indonesia. Malang: Disampaikan dalam Workshop 'Peran wanita dan Fisika' FMIPA UB.

Mason, SF. 1962. A Hystory of Science. New York: Collier.

Siswono. 2004. Ketidaksetaraan Gender Tutup Akses Perempuan Di bidang Iptek. Jakarta: gizi.net.

Slamet, PH. 2001. Pengembangan Manusia Indonesia Berkarakter Teknologi. Jakarta: Puslitbang Dikdasmen.

Subowo, WS. 2000. Women Physicist in Indonesia: What They Are Doing With Physic. Jakarta: Research Center of Physics.

Suctipto. 2001. Kurikulum Pendidikan Teknologi Suatu Kebutuhan Yang Tidak Pernah Terlambat. Jakarta: Balitbang Disdasmen.

Suksesi, K. 2005. Pengarusutamaan Gender Dalam Kelembagaan Riset Ilmu Pengetahuan dan Teknologi (Riptek). Malang: Makalah Disampaikan Dalam Seminar Pengarusutamaan Gender Dalam Program Peningkatan Saran dan Kelembagaan Iptek.

Waejman, J. 2001. Feminisme versus Technology. SDPY-Oxfarm - UK - 1

Wijanarko, N. Pengarusutamaan Gender Dalam Kelembagaan Riset Ilmu Pengetahuan dan Teknologi (Riptek). Malang: Makalah Disampaikan Dalam Seminar Pengarusutamaan Gender Dalam Program Peningkatan Saran dan Kelembagaan Iptek. 